\title{
Histochemical, phytochemical and biological screening of Plinia cauliflora (DC.) Kausel, Myrtaceae, leaves
}

\author{
Tatiana M. Souza-Moreira, ${ }^{1}$ Raquel R. D. Moreira, ${ }^{2}$ Luis V. S. Sacramento, ${ }^{2}$ \\ Rosemeire C. L. R. Pietro ${ }^{*, 1}$
}

${ }^{1}$ Departamento de Fármacos e Medicamentos, Pós-graduação em Ciências Farmacêuticas, Faculdade de Ciências Farmacêuticas, Universidade Estadual Paulista “Júlio de Mesquita Filho”, Rodovia Araraquara-Jaú, km 1, 14801-902 Araraquara-SP, Brasil

${ }^{2}$ Departamento de Princípios Ativos Naturais e Toxicologia, Faculdade de Ciências Farmacêuticas, Universidade Estadual Paulista “Júlio de Mesquita Filho”, Rodovia Araraquara-Jaú, km 1, 14801-902 Araraquara-SP, Brasil.

\begin{abstract}
RESUMO: "Rastreamento histoquímico, fitoquímico e biológico de folhas de Plinia cauliflora (DC.) Kausel (Myrtaceae)". No presente trabalho, foram investigadas a composição química e atividades biológicas de extratos brutos obtidos com etanol 50\%, etanol 70\%, acetona:água (7:3; v/v) e clorofórmio das folhas de Plinia cauliflora (DC.) Kausel, Myrtaceae, uma árvore nativa de várias regiões do Brasil. Os rastreamentos histoquímico e fitoquímico foram feitos de acordo com reações de caracterização e cromatografia em camada delgada. Para auxiliar na padronização dos extratos foram realizadas determinações do teor de fenóis totais e de flavonoides totais, espectrofotometricamente. A atividade antioxidante foi analisada pela porcentagem de sequestro de radicais livres usando solução de DPPH. A atividade antimicrobiana foi avaliada frente a bactérias patogênicas Gram-positivas, Gram-negativas e espécies de Candida utilizando os métodos de difusão em ágar e determinação da concentração inibitória mínima (MIC) de acordo com métodos padronizados. As folhas apresentaram lipídeos nas cavidades secretoras e fenóis, principalmente taninos, nas nervuras e parênquima paliçádico. Os extratos polares apresentaram flavonoides, taninos, alto teor de fenóis totais e de flavonoides totais. Os extratos mostraram elevada atividade antioxidante e a atividade antimicrobiana foi melhor contra as espécies de Candida do que contra as bactérias.
\end{abstract}

Unitermos: Plinia cauliflora, Myrtaceae, rastreamento químico, atividade antioxidante, atividade antimicrobiana.

\begin{abstract}
In this work, chemical and biological activities of crude extracts obtained with 50\% ethanol, 70\% ethanol, acetone:water (7:3; v/v) and chloroform of Plinia cauliflora (DC.) Kausel, Myrtaceae, leaves, a native tree from several regions of Brazil, was investigated. Histochemical and phytochemical screenings were done according to characterization reactions and thin layer chromatography. To assist in extracts standardization, total phenol and flavonoids content spectrophotometric was performed. Antioxidant activity was analyzed by percentage of radical scavenging using DPPH solution. Antimicrobial activity was evaluated against Gram-positive, Gram-negative pathogenic bacteria and species of Candida using agar diffusion and minimal inhibitory concentration (MIC) determination methods according to standard methods. The leaves presented lipids at secretory cavity and phenols, mainly tannins, in nervures and palisade parenchyma. Polar extracts showed flavonoids, tannins and high content of phenols and flavonoids. The extracts showed great antioxidant activity and antimicrobial activity was better against Candida species than against bacteria.
\end{abstract}

Keywords: Plinia cauliflora, chemical screening, antioxidant activity, antimicrobial activity.

\section{INTRODUCTION}

Plinia cauliflora (DC.) Kausel is a plant from the family Myrtaceae, which has one hundred twenty nine genders. The several species from this family are source of essential oils, condiments, food and many of them are used in traditional medicine (Stasi \& Hiruma-Lima, 2002).
Myrciaria cauliflora (Mart.) O. Berg, Myrtus cauliflora Mart., Eugenia cauliflora DC. Myrciaria jaboticaba (Vell.) O. Berg, Myrciaria tenella (DC.) O. Berg and Myrciaria trunciflora $\mathrm{O}$. Berg are scientific synonims of $P$. cauliflora. In Brazil, it is called popularly as "jabuticabeira" or "jaboticaba" (Lorenzi, 2000).

Morphologically, it is a tree about ten-fifteen 
meters of height, which bark scales every year, that has simple leaves, with flowers and fruits together the stem, feature by what this plant has been named. This tree occurs, preferentially, at flood plain and open forests being find at forests from Brazil, Argentine and Paraguay. P. cauliflora produces lots of comestible and delicious fruits twice or more times a year (Lorenzi, 2000; Barros et al., 1996). The bark of $P$. cauliflora is astringent and used by Brazilian people to treat diarrhoea and skin irritations (Lorenzi, 2000).

It has not been scientifically reported the chemical composition and biological properties of the leaves of $P$. cauliflora so that, the purpose of this study was to characterize histochemically and phytochemically the composition and to investigate antioxidant and antimicrobial activities of different crude extracts of these leaves.

\section{MATERIAL AND METHODS}

\section{Plant material and preparation of extracts}

The leaves of Plinia cauliflora (DC.) Kausel (Myrtaceae), collected from São Carlos, Brazil, (22001'16.6”S; 4753'57.0”W) in 2004, were identified by Marcos Sobral and deposited at Herbário da Escola Superior de Agricultura "Luiz de Queiroz", ESALQ, USPPiracicaba, Brazil (voucher ESA n ${ }^{\circ}$ 96038). The leaves were dried at $40{ }^{\circ} \mathrm{C}$ for $4 \mathrm{~d}$, comminuted and percolated individually with $50 \%$ ethanol $(50 \mathrm{EtOH}), 70 \%$ ethanol $(70$ EtOH), acetone:water $(7: 3 ; \mathrm{v} / \mathrm{v})\left(\mathrm{Ac}: \mathrm{H}_{2} \mathrm{O}\right)$ and chloroform $\left(\mathrm{CHCl}_{3}\right)$. The extracts were concentrated under reduced pressure and lyophilization. The yield of each extract was $35 \%, 30 \%, 20 \%$ and $2 \%$, respectively.

\section{Bacterial and fungal strains}

Tests were performed on reference strains obtained from American Type Culture Collection (ATCC): Bacillus subtilis (ATCC 9362); Staphylococcus aureus (ATCC 25923) and Staphylococcus epidermidis (ATCC 12228); Escherichia coli (ATCC 10536); Candida albicans (ATCC 64548); Candida parapsilosis (ATCC 22019); Candida tropicalis (ATCC 750). After overnight growth at $37{ }^{\circ} \mathrm{C}$ the inocula were prepared by adjusting the turbidity of the suspension to match the 0.5 McFarland standard in order to achieve the suitable suspension of $1.5 \times 10^{8}$ bacteria/ $\mathrm{mL}$ and $1.0 \times 10^{6}$ to $5.0 \times 10^{6}$ yeast $/ \mathrm{mL}$ (NCCLS, 2002; NCCLS, 2003a).

\section{Histochemical screening}

Thin transverse sections of the midvein were handmade with a stainless steel razor. Some sections were treated with $2 \%$ sodium hypochloride solution, submitted to ethanol-cetone-hexane sequence, rehydrated, washed with distilled water and used as negative control. Anatomical identification was done with $0.05 \%$ Toluidin Blue in buffer at pH 6.8 (Kraus \& Arduin, 1997). Identification of hydrophilic substances used: ferric chloride for phenolic compounds (Johansen, 1940), vanillin in $\mathrm{HCl}$ (9\%) solution for tannins (Valette et al., 1998) and picric acid for alkaloids. Identification of lipophilic substances used: Sudan red III for total lipids (Johansen, 1940), Nile Blue sulphate for acid and neutral lipids (Cain, 1947), osmium tetroxide for unsaturated lipids (Ganter \& Jollés, 1969-1970), Nadi staining for essential oil and oleoresin (David \& Carde, 1964), antimony trichloride for steroids (Hardman \& Sofowora, 1972), sulphuric acid for sesquiterpene lactones (Geissman \& Griffin, 1971) and 2,4-dinitrophenylhydrazine for terpenoids (Ganter \& Jollés, 1969-1970).

\section{Preliminary phytochemical screening and thin-layer chromatography (TLC) profile}

Powdered leaves were extracted appropriately to perform characterization reactions of secondary metabolites classes according to Henriques et al. (2004), Zuanazzi and Montanha (2004), Schenkel et al. (2004) and Santos and Mello (2004). Dragendorf's, Bouchardat's, Mayer's and Bertrand's reagents were used to indicate the presence of alkaloids by precipitate formation. Flavonoids were characterized by fluorescence by complexation with aluminum chloride visualized at 235 and $355 \mathrm{~nm}$. The formation and persistence of foam after $20 \mathrm{~min}$ of previous agitation and addition of chloridric acid $2 \mathrm{~N}$ was used to characterized saponins. For tannins, it was done precipitation reactions with gelatin, ferric chloride to detect condensed and/or hydrolyzed tannins and lead acetate to detect only hydrolyzed tannin. One-dimensional TLC silica gel analysis of the four extracts was performed in chloroform:methanol:n-propanol:water $(5: 6: 1: 4 ; \mathrm{v} / \mathrm{v})$ and visualized by spraying anisaldehyde/ $\mathrm{H}_{2} \mathrm{SO} 4$ and heating with UV irradiation at $235 \mathrm{~nm}$ and by spraying $1 \%$ ferric chloride in methanol (Wagner et al., 1984).

\section{Determination of total phenolics and total flavonoids}

Total phenolics in the extracts were determined with Folin-Denis reagent according to the method from AOAC (1984). Briefly, $100 \mu \mathrm{L}$ of aqueous solutions (20 $\mathrm{mg} / \mathrm{mL}$ ) of extracts were diluted 1:200 and samples from 0.2 to $0.5 \mathrm{~mL}$ of these solutions were added to $7 \mathrm{~mL}$ of water and $0.5 \mathrm{~mL}$ of Folin-Denis reagent. After $3 \mathrm{~min}$, it was added $1 \mathrm{~mL}$ of $35 \% \mathrm{Na}_{2} \mathrm{CO}_{3}$ solution completing the volume to $10 \mathrm{~mL}$ with water. The absorbance was measured at $760 \mathrm{~nm}$ using Shimadzu UV-1603 spectrophotometer after $30 \mathrm{~min}$. A standard curve was plotted using different concentrations of an aqueous solution of tannic acid. The percentage of total phenolics compound in the extracts was calculated using a linear equation based on the 
standard curve. Total flavonoids content was determined by colorimetrical method described by Djeridane et al. (2006). The extracts $(0.2 \mathrm{~g})$ were dissolved in $20 \mathrm{~mL}$ of $80 \%$ methanol, extracted for $2 \mathrm{~h}$ at room temperature and centrifuged at $3000 \mathrm{~g}$ for $15 \mathrm{~min}$. The volume of the supernatant was made up to $100 \mathrm{~mL}$ with $80 \%$ methanol. A portion of $2 \mathrm{~mL}$ was taken and added to $2 \mathrm{~mL}$ of $2 \% \mathrm{AlCl}_{3}$ methanol solution. The absorbance was measured at 430 $\mathrm{nm}$ after $15 \mathrm{~min}$ at room temperature. A standard curve was plotted using different concentrations of rutin solution in $80 \%$ methanol. The percentage of total flavonoids in the extracts was calculated using a linear equation based on the standard curve.

\section{Antioxidant activity}

Antioxidant potential of the extracts at $250 \mu \mathrm{g} / \mathrm{mL}$ in methanol was evaluated by radical scavenging capacity with $\quad 0.004 \%$ 2,2-diphenyl-1-picryl-hydrazyl (DPPH) in methanol using spectrophotometry at $517 \mathrm{~nm}$. Gallic acid, rutin and vitamin $\mathrm{C}$ were used as positive control $(250 \mu \mathrm{g} / \mathrm{mL})$. It was added $2.50 \mathrm{~mL}$ of DPPH solution to $1.00 \mathrm{~mL}$ of samples, shaked and kept at dark place for 30 min. Blank solutions were done with $1.00 \mathrm{~mL}$ of extract solution added to $2.50 \mathrm{~mL}$ of methanol and negative control consisted of $1.00 \mathrm{~mL}$ of methanol added to $2.50 \mathrm{~mL}$ of DPPH solution. Anti-radical activity was calculated as discolour percentage of DPPH according to the equation: $\%=(\mathrm{DA}-\mathrm{SA} / \mathrm{DA}) .100$; where: DA = DPPH absorbance; $\mathrm{SA}=$ sample absorbance (Falcão et al., 2006).

\section{Antimicrobial assay of crude extracts}

Stock solutions of $100 \mathrm{mg} / \mathrm{mL}$ of each extract were prepared in dimethylsulfoxide (DMSO) and were conveniently diluted in culture medium. All tests were performed according to standard methods and to Ostrosky et al. (2008) review applied for medicinal plants.

\section{Agar diffusion method (NCCLS, 2003b)}

The test was made with $1 \times 10^{6} \mathrm{CFU} / \mathrm{mL}$ in Petri dishes. Steel templates were placed on the solid medium and $50 \mu \mathrm{L}$ of the extracts $(50 \mathrm{mg} / \mathrm{mL}), 50 \mu \mathrm{L}$ of DMSO:BHI (BHI) $(1: 1 ; \mathrm{v} / \mathrm{v})$ and $50 \mu \mathrm{L}$ of ampicillin solution $(50 \mu \mathrm{g} /$ $\mathrm{mL}$ ) were separately added to each well. After $2 \mathrm{~h}$ at 4 ${ }^{\circ} \mathrm{C}$ the plates were incubated at $37{ }^{\circ} \mathrm{C}$ for $24 \mathrm{~h}$. Bacterial growth inhibition was determined by inhibition zones diameter around the wells.

\section{Assay for antimicrobial activity}

Minimal inhibitory concentration (MIC) values were determined by microdilution method (NCCLS, 2002; NCCLS, 2003a). Final dilutions ranging from 5 $\mathrm{mg} / \mathrm{mL}$ to $0.078 \mathrm{mg} / \mathrm{mL}$ of crude extract were prepared in sterile 96-well microplates. The wells were filled with BHI for antibacterial approach; RPMI-1640 medium with $2 \%$ glucose and $0.165 \mathrm{~mol} / \mathrm{L} 3$-[N-morpholine] propanesulfonic acid (MOPS) at $\mathrm{pH} 7$ for antifungal. Final bacterial inocula were $2.5 \times 10^{5} \mathrm{CFU} / \mathrm{mL}$ and incubated aerobically at $35^{\circ} \mathrm{C}$ for $24 \mathrm{~h}$. Final yeast inocula were 2.5 x $10^{3} \mathrm{CFU} / \mathrm{mL}$ incubated at $35^{\circ} \mathrm{C}$ for $48 \mathrm{~h}$ at $100 \mathrm{rpm}$. Ampicillin and amphotericin $\mathrm{B}$ were used as positive control to bacteria and yeast, respectively. Bacterial growth was indicated by addition of $0.01 \%$ resazurin aqueous solution and MIC values were identified as the lowest extract concentration in which no growth is visible showed by changing colour of resazurin from blue (abscence of growth) to pink (growth) (Gabrielson et al., 2002). Yeast growth was indicated by addition of $20 \mu \mathrm{L}$ of 2\% 2,3,5-triphenil tetrazolium chloride (TTC) aqueous solution (Eloff, 1998). Yeast MIC values were identified as the lowest extract concentration in which there was no growth and therefore TTC changed the colour from yellow (absence of growth) to red (growth). Minimal bactericidal concentration (MBC) and minimal fungal concentration (MFC) were determined by subculturing the microplates in Petri dishes with Müller-Hinton-agar for bacteria and Sabouraud-agar for yeast, incubated at $35^{\circ} \mathrm{C}$ for $24 \mathrm{~h}$, and defined as the lowest extract concentration which there was no visible growth of colony.

\section{RESULTS AND DISCUSSION}

It was noted that the leaves of Plinia cauliflora (DC.) Kausel (Myrtaceae) has the same anatomical organization as Myrtaceae family, showing dorsiventral mesophyll emphasing secretory cavities and idioblasts containing calcium oxalate crystals (druseans and monocristals). It was verified the presence of phenols, tannins and alkaloids in midvein and smaller veins; phenols were also verified in palisade parenchyma. Lipids were verified mainly in secretory cavities and reactions were positive for acid and unsaturated lipids, steroids, sesquiterpene lactones and terpenoids; it was noted weak positive result for essential oil. Preliminary phytochemical analysis of the drug showed only the presence of hydrolysable tannins and flavonoids. TLC confirmed these results since three extracts showed two yellow fluorescent spots of flavonoids $\left(\mathrm{R}_{\mathrm{f}}=0.37\right.$ and 0.42$)$ with anisaldehyde/ $\mathrm{H}_{2} \mathrm{SO}_{4}$, heating and observation under UV light and one gray spot of tannin $\left(R_{f}=0.25\right)$. One strong blue spot of tannin $\left(\mathrm{R}_{\mathrm{f}}=0.25\right)$ was observed by spraying ferric chloride $1 \%$ in methanol. In contrary of histochemical reaction, TLC tests did not indicate the presence of alkaloids, which must be investigated. $\mathrm{CHCl}_{3}$ extract showed only a weak blue spot around start point. Terpenoids were detected with anisaldehyde/H2SO4 with spot around $\mathrm{R}_{\mathrm{f}}=1.00$. Except to $\mathrm{CHCl}_{3}$ extract, the three extracts showed content of phenolic compounds higher than $45 \%$. Total flavonoids content were not found in $\mathrm{CHCl}_{3}$ extract and about $1 \%$ in polar extracts (Table 1). 
Table 1. Total phenolic and flavonoid content in the extracts of the leaves of $P$. cauliflora.

\begin{tabular}{ccc}
\hline Extract & Phenolic content (\%) & $\begin{array}{c}\text { Flavonoid content } \\
(\%)\end{array}$ \\
\hline $50 \mathrm{EtOH}$ & $45.84 \pm 1.05$ & $1.36 \pm 0.01$ \\
$70 \mathrm{EtOH}$ & $62.08 \pm 1.36$ & $1.25 \pm 0.03$ \\
$\mathrm{Ac}: \mathrm{H}_{2} \mathrm{O}$ & $60.25 \pm 3.60$ & $1.53 \pm 0.01$ \\
$\mathrm{CHCl}_{3}$ & $0.27 \pm 0.09$ & 0.00 \\
\hline
\end{tabular}

a) value is mean \pm standard deviation.

Polar extracts showed high antioxidant activity, beyond $90 \%$, but significantly smaller than the controls gallic acid, rutin and vitamin $\mathrm{C}$ (Figure 1). Choi et al. (2006) suggested that many biological activities in plants are due to the content of total phenols like flavonoids and tannins. Plant phenols have potential antioxidant activity, mainly by acting as oxygen radical scavengers (Quettier-Deleu et al., 2000). Other studies (Souza et al., 2007; Tadhani et al., 2007) showed that extracts with high content of phenols have high antioxidant activity and that was seen in this study since chloroformic extract exhibited the smaller phenol content and antioxidant activity.

Agar diffusion method showed great inhibition zones (Table 2) for polar extracts. However, MIC and MBC determination of $50 \mathrm{EtOH}, 70 \mathrm{EtOH}$ and $\mathrm{Ac}: \mathrm{H}_{2} \mathrm{O}$ extracts have showed weak antibacterial activity whereas $\mathrm{CHCl}_{3}$ had not any activity at the highest concentration tested (Table 2). The bacteria selected for this study are present in the human being daily as normal microbiota, e.g., Staphylococcus aureus and Staphylococcus epidermidis; as food contaminants, e.g., Escherichia coli or used to sterility control, e.g., Bacillus subtilis (Chomnawang et al., 2005; Beovic, 2006; Abdou et al., 2007; Pesavento et al., 2007). Polar extracts showed great activity against
Candida species and C. tropicalis was more sensible to them since MFC values were the smallest. $\mathrm{CHCl}_{3}$ extract did not showed activity at the highest concentration tested (Table 2). This work had interesting results against Candida species. Candida albicans is the yeast species more often isolated from biological samples being an usual skin and mucosa colonizing agent with many hosts in the oral cavity, and higher incidence rates among young children and patients infected with HIV, but is necessary to pay attention to the emergence of other Candida species as infecting agents (McCullough et al., 1996; Runyoro et al., 2006; Zhang et al., 2006). Resistance to commonly used agents, toxicity and costs impelled the search for new agents and it can be noted that in recent years the research for new active compounds from natural sources has been increasing (Duarte et al., 2005; Runyoro et al., 2006).

Histochemical and phytochemical results showed phenolic prevalence in the composition of the leaves and extracts of $P$. cauliflora and can contribute to the standardization of the extracts. Besides, it was possible to indicate that polar extracts of the leaves have biological activities as antioxidant and antimicrobial that can be due to their phenolic content. It should be emphasize the presence of flavonoids and tannins derivates in polar extracts and the activity against Candida species showed by them. It was noticed that $\mathrm{CHCl}_{3}$ extract showed small composition of phenolic content, therefore it could explain the smallest antioxidant and antimicrobial activities.

This study is important since it is the first to indicate the leaves extracts of P. cauliflora as new source of antioxidant and antimicrobial molecules and because it was determined the composition of the leaves. These investigations showed a preliminary standardization of the leaves by histochemical and phytochemical methods.

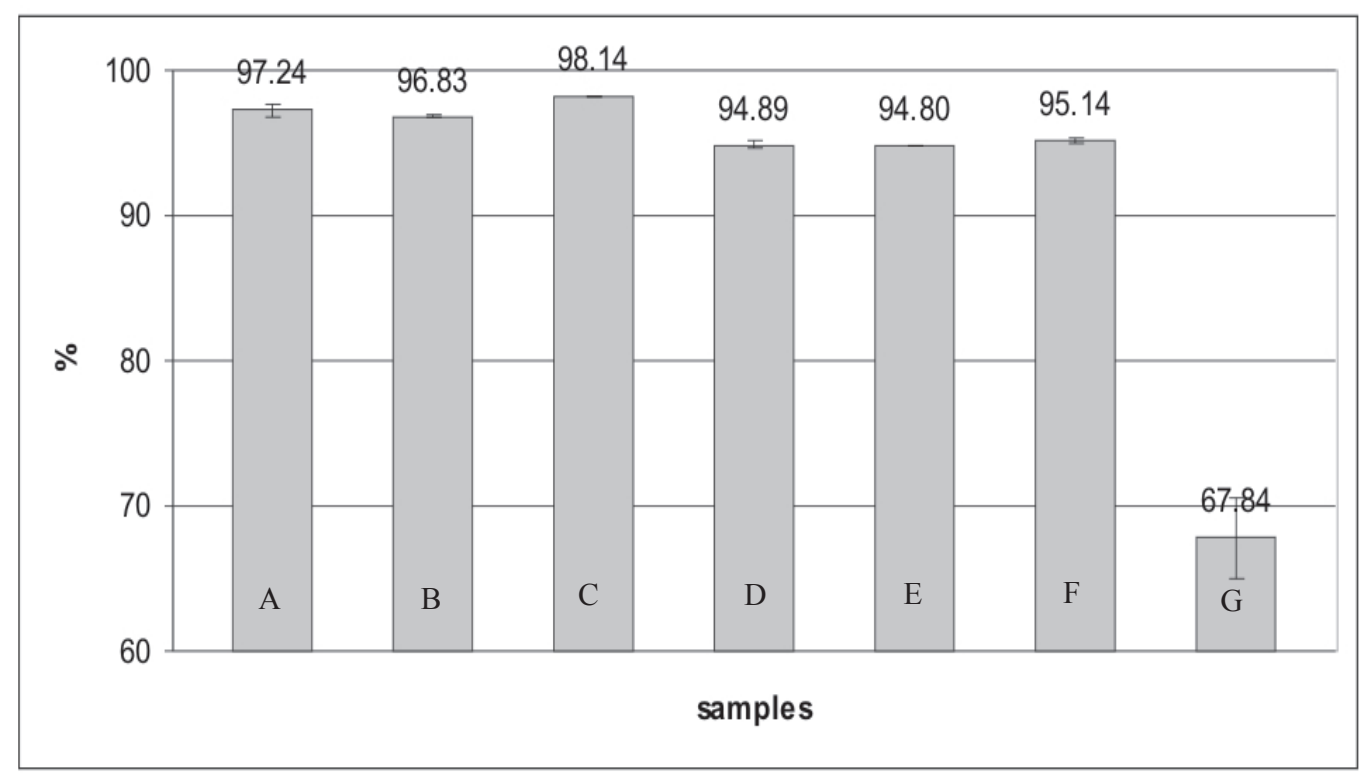

Figure 1. Radical scavenging capacity. Percentual \pm standard deviation. A) gallic acid. B) rutin. C) vitamin C. D) 50 EtOH extract. E) $70 \mathrm{EtOH}$ extract. F) Ac: $\mathrm{H}_{2} \mathrm{O}$ extract. G) $\mathrm{CHCl}_{3}$ extract. 
Table 2. Antimicrobial activity of $P$. cauliflora leaves extracts.

\begin{tabular}{|c|c|c|c|c|c|c|c|c|c|c|c|}
\hline \multirow{2}{*}{ Samples } & \multicolumn{4}{|c|}{ Inhibition zone ${ }^{a}$} & \multicolumn{4}{|c|}{$\mathrm{MIC} / \mathrm{MBC}^{\mathrm{b}}$} & \multicolumn{3}{|c|}{$\mathrm{MIC} / \mathrm{MFC}^{\mathrm{c}}$} \\
\hline & $S a$ & $\mathrm{Se}$ & $B s$ & $E c$ & $S a^{*}$ & $S e^{*}$ & $B s^{*}$ & $E c^{*}$ & $\mathrm{Ca}^{*}$ & $C p^{*}$ & $C t^{*}$ \\
\hline $50 \mathrm{EtOH}$ & $18.1 \pm 1.6$ & $19.3 \pm 2.0$ & $19.1 \pm 1.2$ & $19.0 \pm 1.7$ & $5.0 / 5.0$ & $5.0 / 5.0$ & $>5.0 />5.0$ & $5.0 / 5.0$ & $0.62 />10$ & $0.62 />10$ & $0.62 / 1.25$ \\
\hline $70 \mathrm{EtOH}$ & $18.4 \pm 1.0$ & $18.7 \pm 0.5$ & $18.1 \pm .2$ & $18.1 \pm 2.0$ & $5.0 / 5.0$ & $5.0 / 5.0$ & $>5.0 />5.0$ & $5.0 />5.0$ & $0.62 />10$ & $0.62 />10$ & $0.62 / 2.50$ \\
\hline Ac: $\mathrm{H}_{2} \mathrm{O}$ & $18.7 \pm 1.2$ & $20.1 \pm 1.5$ & $19.5 \pm 0.3$ & $19.6 \pm 1.7$ & $5.0 / 5.0$ & $5.0 / 5.0$ & $>5.0 />5.0$ & $5.0 />5.0$ & $0.62 />10$ & $0.62 />10$ & $0.62 / 1.25$ \\
\hline $\mathrm{CHCl}_{3}$ & - & - & - & - & $>5.0 />5.0$ & $>5.0 />5.0$ & $>5.0 />5.0$ & $>5.0 />5.0$ & $>10 />10$ & $>10 />10$ & $>10 />10$ \\
\hline$a m p * *$ & $15.0 \pm 0.8$ & $14.7 \pm 0.6$ & $15.1 \pm 0.2$ & $15.0 \pm 0.6$ & $3.1 / 3.1$ & $1.6 / 1.6$ & $1.6 / 1.6$ & $1.6 / 1.6$ & n.e. & n.e. & n.e. \\
\hline $\operatorname{amphB}^{* *}$ & n.e. & n.e. & n.e. & n.e. & n.e. & n.e. & n.e. & n.e. & $0.25 / 0.25$ & $0.25 / 0.25$ & $0.25 / 0.25$ \\
\hline
\end{tabular}

Sa: Staphylococcus aureus; Se: Staphylococcus epidermidis; Bs: Bacillus subtilis; Ec: Escherichia coli; Ca: Candida albicans; Cp: Candida parapsilosis; Ct: Candida tropicalis. amp: ampicillin; amphB: amphotericin B; a) values expressed, in milimeters, as mean of three determinations \pm standard deviation; b) MIC and MBC determination; c) MIC and MFC determination; -: no inhibition; n.e.: not evaluated; * values expressed in $\mathrm{mg} / \mathrm{mL}$; ** values expressed in $\mu \mathrm{g} / \mathrm{mL}$.

\section{ACKNOWLEDGEMENTS}

This work was supported by CAPES, FAPESP and PADC-FCF-UNESP. The authors wish to thank Juliana A. Severi and Prof. Dr. Wagner Vilegas from Departamento de Química Orgânica, Instituto de Química, UNESP, Araraquara-SP, Brazil for phytochemical help. We also thank Luís Eduardo dos Santos and Maria Angélica Lima Barretto for technical assistance.

\section{REFERENCES}

Abdou AM, Higashiguchi S, Aboueleinin AM, Kim M, Ibrahim HR 2007. Antimicrobial peptides derived from hen egg lysozyme with inhibitory effect against Bacillus species. Food Control 18: 173-178.

AOAC-Association of Official Analytical Chemists 1984. Official methods of analysis of the association of chemists. 13 . ed. Washington, D.C.: Association of Official Analytical Chemists.

Barros RS, Finger FL, Magalhães MM 1996. Changes in nonstructural carbohydrates in developing fruit of Myrciaria jaboticaba. Sci Hortic-Amsterdam 66: 209-215.

Beovic B 2006. The issue of antimicrobial resistance in human medicine. Int J Food Microbiol 112: 280-287.

Cain AJ 1947. The use of Nile Blue in the examination of lipids. Q J Microsc Sci 88: 383-392.

Choi YM, Noh DO, Cho SY, Suh HJ, Kim KM, Kim JM 2006. Antioxidant and antimicrobial activities of propolis from several regions of Korea. LWT-Food Sci Technol 39: 756761.

Chomnawang MT, Surassmo S, Nukoolkarn VS, Gritsanapan W 2005. Antimicrobial effects of Thai medicinal plants against acne-inducing bacteria. J Ethnopharmacol 101: 330-333.

Costa AF 1994. Farmacognosia. Lisboa: Calouste Gulbenkian.

David R, Carde JP 1964. Coloration différentielle des inclusions lipidique et terpeniques des pseudophylles du Pin maritime au moyen du reactif Nadi. $C R$ Hebd Seances Acad Sci D 258: 1338-1340.

Djeridane A, Yousfi M, Nadjemi B, Boutassouna D, Stocker P, Vidal N 2006. Antioxidant activity of some Algerian medicinal plants extracts containing phenolic compounds. Food Chem 97: 654-660.
Duarte MCT, Figueira GM, Sartoratto A, Rehder VLG, Delarmelina C 2005. Anti-Candida activity of Brazilian medicinal plants. J Ethnopharmacol 97: 305-311.

Eloff JN 1998. A sensitive and quick microplate method to determine the minimal inhibitory concentration of plant extracts for bacteria. Planta Med 64: 711-713.

Falcão DQ, Costa ER, Alviano DS, Alviano CS, Kuster RM, Menezes FS 2006. Rev Bras Farmacogn 16: 73-76.

Gabrielson J, Hart M, Jarelöv A, Kuhn I, Mckenzie D, Möllby R 2002. Evaluation of redox indicators and the use of digital scanners and spectrophotometer for quantification of microbial growth in microplates. J Microbiol Meth 50: 63-73.

Ganter P, Jollés G 1969-1970. Histochimie normale et pathologique. Paris: Gauthier-Villars.

Geissman TA, Griffin TS 1971. Sesquiterpenes lactones: acidcatalyzed color reactions as an aid structure determination. Phytochemistry 10: 2475-2485.

Hardman R, Sofowora EA 1972. Antimony trichloride as test reagents for steroids, specially diosgenin and yamogenin, in plant tissues. Stain Technol 47: 205-208.

Henriques AT, Limberger RP, Kerber VA, Moreno PRH 2004. Alcalóides: generalidades e aspectos básicos. In: Simões CMO, Schenkel EP, Gosmann G, Mello JCP, Mentz LA, Petrovick PR 2004. Farmacognosia: da planta ao medicamento. 5. ed. Porto Alegre/ Florianópolis: Ed. Universidade/ UFRGS/ Ed. da UFSC. p. 765-792.

Johansen DA 1940. Plant Microtechnique. New York: McGrawHill.

Kraus JE, Arduin M 1997. Manual básico de métodos em morfologia vegetal. Rio de Janeiro: Edur.

Lorenzi H 2000. Árvores brasileiras: manual de identificação e cultivo de plantas arbóreas nativas do Brasil. São Paulo: Instituto Plantarum.

McCullough MJ, Ross BC, Reade PC 1996. Candida albicans: a review of its history, taxonomy, epidemiology, virulence attributes, and methods of strain differentiation. Int $J$ Oral Max Surg 25: 136-144.

National Committee for Clinical Laboratory Standards 2002. Method broth dilution antifungal susceptibility testing of yeasts. 2. ed. Approved Standard. NCCLS document M27-A2. Wayne, Pennsylvania: NCCLS.

National Committee for Clinical Laboratory Standards 2003a. Methods for dilution antimicrobial susceptibility tests for bacteria that grow aerobically. 6. ed. Approved Standard. NCCLS document M7-A6. Wayne, Pennsylvania: 
NCCLS.

National Committee for Clinical Laboratory Standards 2003b. Performance standards for antimicrobial disk susceptibility tests. 8. ed. Approved Standard. NCCLS document M2-A8. Wayne, Pennsylvania: NCCLS.

Ostrosky EA, Mizumoto MK, Lima MEL, Kaneko TM, Nishikawa SO, Freitas BR 2008. Métodos para avaliação da atividade antimicrobiana e determinação da concentração mínima inibitória (CMI) de plantas medicinais. Rev Bras Farmacogn 18: 301-307.

Pesavento G, Ducci B, Comodo N, Lo Nostro A 2007. Antimicrobial resistance profile of Staphylococcus aureus isolated from raw meat: A research for methicillin resistant Staphylococcus aureus (MRSA). Food Control 18: 196-200.

Quettier-Deleu C, Gressier B, Vasseur J, Dine T, Brunet C, Luyckx M, Cazin M, Cazin JC, Bailleul F, Trotin F 2000. Phenolic compounds and antioxidant activities of buckwheat (Fagopyrum esculentum Moench) hulls and flour. J Ethnopharmacol 72: 35-42.

Runyoro DKB, Ngassapa OD, Matee MIN, Joseph CC, Moshi MJ 2006. Medicinal plants used by Tanzanian traditional healers in the management of Candida infections. $J$ Ethnopharmacol 106: 158-165.

Santos AC, Mello JCP 2004. Taninos. In: Simões CMO, Schenkel EP, Gosmann G, Mello JCP, Mentz LA, Petrovick PR 2004. Farmacognosia: da planta ao medicamento. 5. ed. Porto Alegre/ Florianópolis: Ed. Universidade/ UFRGS/ Ed. da UFSC. p. 615-656.

Schenkel EP, Gosmann G, Athayde ML 2004. In: Simões CMO, Schenkel EP, Gosmann G, Mello JCP, Mentz LA, Petrovick PR 2004. Farmacognosia: da planta ao medicamento. 5. ed. Porto Alegre/ Florianópolis: Ed. Universidade/ UFRGS/ Ed. da UFSC. p. 711-740.

Souza TM, Severi JA, Silva VYA, Santos E, Pietro RCLR 2007. Bioprospecção de atividade antioxidante e antimicrobiana da casca de Stryphnodendron adstringens (Mart.) Coville (Leguminosae-Mimosoidae). Rev Cienc Farm Basica Apl 28: 221-226.

Stasi LC, Hiruma-Lima CA 2002. Myrtales medicinais. In: Stasi LC, Hiruma-Lima CA. Plantas Medicinais na Amazônia e na Mata Atlântica. 2. ed. São Paulo: Editora UNESP, p. 321-330.

Tadhani MB, Patel VH, Subhash R 2007. In vitro antioxidant activities of Stevia rebaudiana leaves and callus. J Food Compost Anal 20: 323-329.

Valette C, Andary C, Geiger JP, Sarah JL, Nicole M 1998. Histochemical and cytochemical investigations of phenols in roots of banana infected by the burrowing nematode Radopholus similes. Phytopathology 88: 11411148 .

Wagner H, Bladt S, Zgainski EM 1984. Plant Drug Analysis. Berlin: Springer-Verlag.

Zhang JD, Xu Z, Caoa YB, Chenb HS, Yan L, An MM, Gao PH, Wang Y, Jia XM, Jiang YY 2006. Antifungal activities and action mechanisms of compounds from Tribulus terrestris L. J Ethnopharmacol 103: 76-84.

Zuanazzi JAS, Montanha JA 2004. Flavonóides. In: Simões CMO, Schenkel EP, Gosmann G, Mello JCP, Mentz LA, Petrovick PR. Farmacognosia: da planta ao medicamento. 5. ed. Porto Alegre/ Florianópolis: Ed. Universidade/ UFRGS/ Ed. da UFSC, p. 577-614. 